\section{Putting the "Us" Back in the U.S. Defense Industrial Base: The Case of Rare Earths}

\author{
Raeanna L. Carrell ${ }^{1}$ \\ 1rlmcfadd@iu.edu
}

As a nation, the United States is committed to the ideals of a free market economy - that competition among firms leads to greater levels of efficiency. The operation of the U.S. defense industrial base is no exception. It relies on both public-sector (government owned/operated) and private-sector (commercial) firms for the procurement of materials, products, and services necessary to properly equip America's Warfighters. Indeed, the defense industrial base is diverse, complex, and global. As such, the Department of Defense (DOD) has always relied to some extent on production that takes place in foreign firms, particularly at the sub-tier level ${ }^{1}$.

The end of the Cold War led to a reduction in U.S. military spending and a greater reliance on market forces (and private sector firms) to support the defense industrial base. The foreign share of the defense industrial base grew. Today, the defense industrial base is totally reliant on foreign nations for the procurement of each of the following: electronics (Department of Defense 2018); high-tenacity, military grade polyester fiber (Department of Defense 2018); certain specialty chemicals for munitions and missile use (Metal/Center News 2013); proprietary carbon fibers used in missiles, satellites, space launches, and other purposes (Department of Defense 2018); and image intensifier tube core glass critical to U.S. night vision systems (Department of Defense 2018).

A contemporary national security problem is U.S. dependence on strategic competitor nationsthose nations (e.g., Russia and China) that aim to upset the current international order and, more

\footnotetext{
${ }^{1}$ Suppliers, distributors, vendors, or firms that furnish supplies or services to or for a prime subcontractor or another sub-tier contractor
}

specifically, undercut U.S. global preeminence. According to the Department of Defense (2018), this problem stems from two macroeconomic factors: (1) the decline of U.S. civilian manufacturing base capabilities and (2) the rise of competitor nations.

The DOD report (2018) placed great emphasis on China as the primary revisionist power threat to U.S. national security via the defense industrial base. China's strategy of economic expansion has for many years employed both legal and illicit means to undermine free market principles and increase its global market share of critical materials and technologies (United States Trade Representative 2018). As a result, the U.S. is dependent on China for many materials critical to the health and function of the defense industrial base.

Rare earth minerals represent a particularly significant example of U.S. dependence on China. Indeed, rare earths can be considered a critical case study (Yin 1994) of foreign dependence-if the U.S. can successfully lower the national security risk for this class of compounds, then it can successfully manage other cases of foreign dependence that pose a similar or less significant threat. This paper describes a discrete set of policy options for increasing the resiliency of the U.S. defense industrial base to supply shocks from China and a strategy formulation process based on these discrete options.

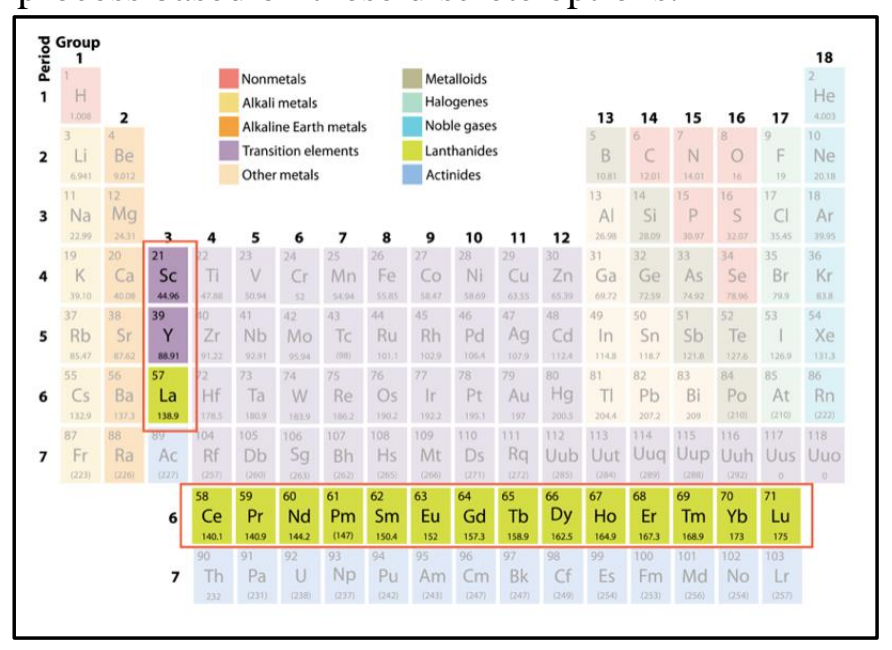

Figure 1. Source: Rare Element Resources (Rare Element Resources 2016) 


\section{The Rare Earth Elements}

$\begin{array}{llll}\text { Sc Scandium } & \text { Nd Neodymium } & \text { Gd Gadolinium } & \text { Er Erbium } \\ \text { Y Yttrium } & \text { Pm Promethium } & \text { Tb Terbium } & \text { Tm Thulium } \\ \text { La Lanthanum } & \text { Sm Samarium } & \text { Dy Dysprosium } & \text { Yb Ytterbium } \\ \text { Ce Cerium } & \text { Eu Europium } & \text { Ho Holmium } & \text { Lu Lutetium } \\ \text { Pr Praseodymium } & & & \end{array}$
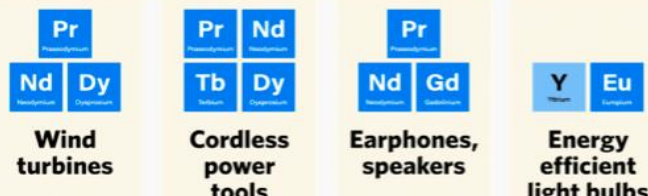

Energy

efficient
light bulbs
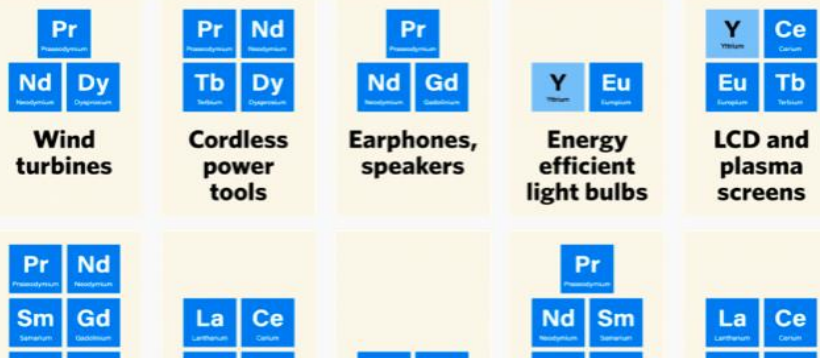

Tb Dy

Hybrid

vehicles,

magnets
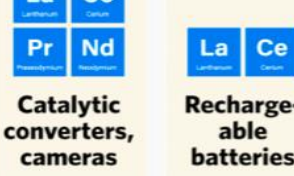

Recharge-

able

batteries
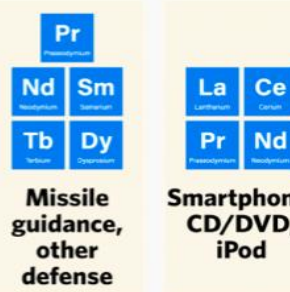

Smartphone, CD/DVD,

iPod

Figure 2. Source: Stratfor Worldview (2019)

\section{WHAT ARE RARE EARTHS?}

Rare Earth Elements (REEs) are a set of 17 metallic elements (Figure 1) which are abundant in number but occur in low concentrations in the Earth's crust. Mining and refining REEs is economically costly; however, due to their unique magnetic, luminescent, and electrochemical properties, rare earths are responsible for breakthroughs in producing technologies that are lighter, smaller, more thermally durable, and more efficient or emissions friendly, among other improvements (Rare Earth Technology Alliance 2018). Figure 2 lists modern-day products made from rare earth elements. The largest segment of consumption for rare earth elements (and fastest growing segment) is permanent magnets, which represent $31 \%$ of global consumption in 2016 (Gayonnet 2018). Permanent magnets based on rare earth elements are used in virtually all high-tech products (e.g., smart phones and other electronics), including those used in aerospace and defense applications.

Ensuring that the defense industrial base has a secure and adequate supply of rare earth elements is a matter of national security. Between 2016 and 2017, the United States did not mine any rare earth

elements domestically after the Mountain Pass mine in California was put on care and maintenance status in the fourth quarter of 2015 (U.S. Geologicial Survey 2018). Consequently, the U.S. was entirely reliant on foreign nations for the procurement and supply of rare earth elements. In 2018, the Mountain Pass mine restarted and the U.S. produced 15,000 metric tons of rare earths (United States Geological Survey 2019); however, most of those rare earths had to be sent overseas to be refined and processed into usable product (Gabriel 2019). In particular, the United States is almost entirely reliant on China - a strategic competitor, as China has captured $90-95 \%$ of the world's market for mining and refining rare earths (Grasso 2013). Rare earths are critical components in more than 200 high-tech electronics and devices produced both for consumer and military use (Grasso 2013), and are critical for the functionality of several defense applications such as lasers, guidance systems, and radar and sonar systems (American Geosciences Institute 2018). They are critical in every domain - air, land, sea, space and cyberspace.

\section{THE 2010 SENKAKU ISLAND DISPUTE}

Should China choose to flex its soft power by restricting rare earth element (REE) exports, the U.S. defense industrial base could be significantly disrupted in the near term. Such concern is based on history: the Japanese and Chinese governments have long disputed which of the two countries is the rightful sovereign over a group of uninhabited islands, the Senkaku Islands. In 2010, China embargoed REE's to Japan in response to a maritime dispute over jurisdiction of the Senkaku Islands in the South China Sea (Grasso 2013). This supply disruption had spillover effects in the U.S. as well. The United States relied - and relies still—on Japan for the procurement of permanent magnets and other REE components (Bradsher 2010). The 2010 embargo lasted for nearly two months. In that time, 
Japan experienced significant shortages, China refused to increase REE exports to any other country to make up for the gap in supply, and the price of REE experienced a global price spike of nearly ten times greater than pre-embargo prices (Bradsher 2010).

The price spike, initiated by Chinese action and driven by market speculation, was temporary. By the end of 2010, prices tumbled as the market adjusted and other nations reclaimed the ability to produce their own supply of rare earths. Starting in the 1980s, China scale up its rare earth mining capabilities dramatically. By the 1990s, the strategy had paid off. China essentially controlled the global rare earth market (Plumer 2012). Vekasi (2019) attributed China's dominant market share in rare earths to low production costs (e.g., labor costs), lower environmental standards, and its state-directed investment strategy.

The 2010 incident resulted in demand destruction for the Chinese-controlled rare earth market, proving that it did not possess monopoly power. Japan developed a method for recycling rare earth elements from used electronics. In the U.S., the Mountain Pass mine in California resumed operation (it closed again in late 2015). Other companies started substituting other materials for rare earths in products, suggesting that rare earths were not always necessary. The United States, followed by the European Union and Mexico, filed a World Trade Organization (WTO) case against China, alleging that its rare earth export quotas violated the rules. The WTO agreed, and forced China to abandon the practice (Bradsher 2012).

The 2010 embargo and its aftermath demonstrate the power of the market to adjust to abrupt changes in supply and demand. Nevertheless, it also demonstrates the threat of supply shocks to U.S. national security, and the need for greater resilience in the defense industrial base to withstand future supply shocks. Since the 2010 embargo, little

\footnotetext{
${ }^{2}$ Appendix A: John S. McCain National Defense Authorization for Fiscal Year 2019. 2018. Government Publishing Office.
}

has changed in the market landscape: China retains market power as a supplier of rare earths, controlling roughly $90 \%$ of the market (Gayonnet 2018).

\section{IDENTIFYING POLICY OPTIONS}

Since the Senkaku Islands dispute in 2010, Congress has pushed the Department of Defense to develop a strategy to reduce its dependence on China for rare earth elements (GAO 2016). Most recently, in the 2019 National Defense Authorization Act (i.e., the John S. McCain National Defense Authorization Act for Fiscal Year 2019), Congress prohibited DOD from procuring the two major types of rare earth magnets - samarium-cobalt and neodymium-ironboron-from "non-allied foreign nations": Russia, China, Iran, or North Korea (Government Publishing Office 2018). The new law allows exceptions in cases where the U.S. cannot procure materials listed in the statute elsewhere, because they are either not available or are not affordable ${ }^{2}$. Since China continues to corner approximately $90 \%$ of the rare earth market, it is reasonable to think that the U.S. will use this exception to continue to procure rare earth magnets from China, at least in the short term.

How can DOD enhance its resiliency to future supply shocks from China? A review of government reports and the academic literature suggest four options from which a strategy can be crafted:

1. Maintain the status quo

2. Develop domestic supply

3. Partner with strategic allies

4. Innovate (through substitution and/or recycling)

\section{Maintain the Status Quo}

The 2010 Senkaku Islands incident and its aftermath have led some observers to suggest that China has less power over global supply than its market concentration would suggest. Wilson argued that China's ability to use rare earths for diplomatic coercion is weak due to several factors: significant 
supplies in other countries that can come on-line relatively quickly (within 1-2 years), global demand that is relatively elastic (through substitution and conservation), China's inability to clamp down on illegal mining and exports, and the WTO ruling (Wilson 2018). Vekasi argued that China's policies on rare earths (restricting exports) have less to do with geopolitics and more to do with environmental stewardship (cracking down on illegal mining) and economic nationalism (Vekasi 2019). To these observers, the global response to China's policies in 2010 provide support for the status quo.

It is important to note that the status quo changed as a result of the 2010 incident. The U.S. began stockpiling rare earths, reopened the Mountain Pass mine (which closed again in 2015, and then reopened in 2018), won key cases at the WTO against Chinese policies, forged stronger ties with strategic allies, and initiated $R \& D$ to advance recycling. Newly enacted legislation will push DOD to foster alternative supply chains for permanent magnets. This new status quo can be expected to increase U.S. resiliency compared to 2010. It is unknown whether this increased resiliency will be sufficient.

\section{Develop Domestic Supply}

A policy of developing domestic supply includes restarting or expanding mining operations in the U.S., creating U.S. capability for processing rare earth oxides, and stockpiling key materials in case of a supply shock.

Until the 1990's, the United States was a major producer of rare earths (Bourzac 2011). The Mountain Pass mine in California, for example, was a major domestic producer of rare earths from 19651985. China's aggressive push to corner the global rare earth market led it to shutter operations in 2002. Following China's 2010 rare earths embargo on Japan, the Mountain Pass mine briefly resumed operations between 2012 and 2015, but closed again in late 2015 due to renewed market competition with China (Roos 2017). In 2018, the mine opened once again. Sources indicate that the Mountain Pass mine was the only operational rare earths mine in the U.S (MP Materials 2019, Wyoming Mining Association 2019). This would indicate that most of the 15,000 metric tons of rare earths mined in the U.S. in 2018 were mined at the Mountain Pass mine. 170,000 metric tons of rare earths were mined globally in 2018, so the Mountain Pass mine could have accounted for approximately $8.8 \%$ of global rare earths production in 2018, based on USGS data (United States Geological Survey 2019). Analysts have speculated that domestically capturing even 5\% of annual global rare earth extraction and production could be enough to give the U.S. the supply security it needs to protect the national security interests related to rare earths (Roos 2017). Even so, without intervention from the U.S. Government, the mine will still struggle to be profitable and competitive due to its small market share.

Intervention is not unprecedented. Title III of the Defense Production Act of 1950, confers broad authority to the President to provide appropriate economic incentives to protect, restore, or expand the U.S. defense industrial base. The DOD, through the DPA Title III program, is responsible for administering the President's Title III authority (Department of Defense).

When the last beryllium reduction plant in the U.S. closed in 2000, a new plant was established using Title III authority. The DPA Title III Program's business case for this military-sponsored plant included plans to ensure its commercial viability, and a marketing strategy was prepared regarding the commercial and military demand for beryllium. The plant is now operational and has successfully secured a continuous domestic supply of beryllium (Air Force Research Library, ManTech 2013).

Title III advantages could also be leveraged, then, to offset start-up operating costs for domestic rare earths mines, helping U.S.-mined rare earth metals to become more attractive to private companies currently sourcing their rare earths needs from China.

The Bear Lodge Project in Northeastern Wyoming could be a prime candidate for Title III 
intervention as well. The proposed Bear Lodge mine is situated in a mining district rich in critical rare earths deposits. Critical rare earths are those elements which are less common in the earth's core, making them more highly valued (Rare Element Resources 2016). The Bear Lodge Project has been in development since 2011. Despite securing key permits, the project was placed on an indefinite hold in 2016 due to a lack of financing caused by poor market conditions (Fladager 2016). Title III authorities could provide Bear Lodge with the steady investment needed to get it up and running.

The DOD could also exercise Title III authorities to finance the construction and operation of new rare earths mining facilities; however, without significant reform to the current permit process operation of new mines would likely be more than a decade out due to unnecessary redundancies and other systemic permitting issues (Canan 2006).

Redundant permitting processes in the U.S. have created webs of red tape, resulting in long project delays and sunk costs. Environmental impact assessments - which often sprawl across multiple agencies, and never-ending legal battles with environmental groups have also imposed significant delays and high costs on mining projects.

These high economic and opportunity costs, coupled with China's lax environmental and permitting standards, are a big reason rare earths mining activity has dried up in the United States (Gayonnet 2018, Vekasi 2019). It is entirely possible that private firms would be interested in pursuing domestic mining projects - either restarting existing mining operations or building new ones - if not for these hurdles.

Title 41 of the Fixing America's Surface Transportation (FAST) Act could provide states with a road map for reform. The FAST Act authorizes federal surface transportation (highway) spending through fiscal year 2020. Title 41 of the Act streamlines the federal permitting process for major infrastructure projects through interagency coordination and deadlines for permit decisions, increasing transparency of permit processing, and establishing statutory limitations for bringing litigation challenging permitting decisions. The scope of FAST 41 is unclear. Some groups have argued that the law can be interpreted to include even mining projects, which are not traditionally classified as "infrastructure" (Jensen et al. 2016). Others disagree; however, one thing is undisputed: the FAST Act does not preempt state-level permitting processes. This is a significant drawback for mining projects in particular, since it is state and local regulations that are hindering the development of new U.S. mining operations (Rupp 2019). It is highly unlikely that Congress will amend FAST 41 to expressly cover mining.

After the 2010 incident, new mining operations were brought on-line to take advantage of the spike in rare earth prices. Many of these mines, many of which have since closed when prices returned to "normal," are controlled or owned by the Chinese, ensuring Chinese control of rare earth supplies (Kennedy 2019).

Ensuring a domestic supply of rare earths lies not just with mining, but with the processing of rare earth oxides (the products of mining) into rare earth elements. According to Kennedy (2019), every rare earth mine outside of China ships its rare earth oxides to China for processing. To build U.S. supply requires processing capabilities that could take a long time to develop — at least 15 years, according to a 2016 GAO report. According to Kennedy, the growth of China as a major supplier began in 1980, when the international Atomic Energy Agency (IAEA) issued regulations treating thorium-bearing byproducts of iron mining as nuclear material. These regulations stopped mining companies in western nations from recovering heavy rare earth minerals, which they did before the 1980 regulations. China is not a signatory to the IAEA and does not have to abide by its regulations (Kennedy 2019).

Stockpiling is another way to build U.S. domestic supply. The Strategic and Critical Materials Stockpiling Act of 1939 (SCMA) provides authority for the U.S., through the Defense Logistics Agency 
(DLA), to purchase critical materials and reserve them for use in times of war. Since 2015, the Defense Logistics Agency (DLA) - a part of DOD — has included the rare earth elements dysprosium and yttrium on its list of strategic materials that may be acquired for stockpiling. Since 2017, that list has also included the rare earth element europium (Defense Logistics Agency). Among other uses, dysprosium is found in missile guidance systems and other defense applications, while yttrium and europium are found in LCD and plasma screens (Stratfor Worldview 2019).

\section{Partner with Strategic Allies}

The U.S. military works closely with a small group of allied nations to facilitate the integration of and coordination among the member nations' defense industries. The framework, called the National Technology and Industrial Base (NTIB) is comprised of the United Kingdom, Canada, Australia and the United States, and represents the highest tier of U.S. defense allies. As part of the mission to develop an NTIB national security strategy, 10 U.S. Code $\$ 2501$ sets forth ten objectives of the NTIB, including ensuring reliable sources of materials critical to national security, including rare earths (Legal Information Institute 2016). The Pentagon assesses each NTIB member's defense industrial base and capabilities into the U.S. defense strategy and includes these assessments into its annual assessment of the U.S. defense industrial base (Thomas-Boone 2017). Business and government leaders alike have expressed keen interest in leveraging their nation's membership in the NTIB to explore new collaboration strategies to mitigate threats posed by China.

The DOD can lean into its allied partners in the National Technology and Industrial Base (NTIB). Aggressively pursuing partnerships with these strategic allies to mine, refine, and distribute rare earths could prove an effective strategy for busting up China's near-monopoly on the market, while simultaneously achieving its objective to provide a reliable supply of rare earths to the defense industrial base.
The Australian mining company Lynas Corporation represents a particularly promising partnership opportunity. In 2011, Lynas Corporation expanded its rare earths extracting and processing operations into Australia. In 2010, Lynas Corporation expressed serious interest in pursuing a partnership with the United States Congress to include the corporation in any plans to stockpile rare earths, touting its position as a corporation based in the state of a key U.S. ally (Chovanec 2010). Most recently, Lynas proposed building a processing operation for the industry in Texas, in light of renewed trade tensions between the U.S. and China. If this project comes to fruition, it would be the only rare earths separation facility in the U.S. (Areddy 2019).

\section{Innovate}

\section{Develop Substitutions}

Ensuring that U.S. defense rare earths needs are met does not necessarily require a secure supply of rare earths. Substitutions, although an immature space today, has the potential to replace at least some rare earths needs. Two ready substitutions exist, for example, for the rare earth permanent magnet neodymium, which is commonly used in motors and generators (Lovins 2017). One such substitute is a neodymium-iron-boron hybrid constituted of a quarter neodymium, and three-quarters iron and boron by weight. This hybrid exhibits the same amount of strength as a pure neodymium magnet.

The other substitution, an induction and switched reluctance motor substitution model, does not require the use of rare earths at all. Unfortunately, neither substitution is currently suitable for wide use in military applications. Defense applications often require high tolerance to intense heat exposure - a feature these substitutions have not sufficiently demonstrated.

Rare earths substitution in military applications is currently constrained by financial viability. A 2013 Congressional Research Service report found that the use of substitute materials in military applications would likely cause significant 
increases in acquisition costs throughout the entire rare earths supply chain, including costs associated with implementing the engineering changes necessary for ensuring equipment functionality (Grasso 2013). A lack of research and development for rare earth substitution possibilities is also constraining the use of substitutions (Lovins 2017). Resources connected to DOD's Manufacturing Technology (ManTech) program and the Department of Commerce's Manufacturing USA program could be leveraged in furthering the development of rare earth substitutions. Both programs are aimed at closing such gaps in manufacturing capabilities of the U.S. defense industrial base. The ManTech program's mission is to provide more affordable, timely, and low-risk manufacturing capabilities for the defense industrial base. ManTech achieves this mission by improving manufacturing-related technology, business practices, and workforce (Department of Defense 2018, 34). Manufacturing USA initiatives aspire to create public-private partnerships between industry and academia to promote technological innovation in advanced manufacturing. Each initiative is centered on developing a specific area of advanced manufacturing (Department of Defense 2018, 36). Both programs could provide the financial means for industry and research universities to aggressively pursue the development of substitution solutions that can meet DOD needs.

\section{Recycling}

The possibility of extracting rare earths from coal ash is currently being explored as a promising alternative to traditional mining and refining techniques (Lesley 2018). Ucore Rare Metals Inc., a U.S. subsidiary of the Canadian-based company Ucore Rare Metals is a company that works in the development stage of the mining process, particularly in rare earths (Ucore).

Currently, Ucore Rare Metals Inc. is operating a pilot facility in Salt Lake City, Utah to provide "proof of concept" for a new process to separate rare earth elements from non-traditional sources, such as coal ash. The process uses molecular recognition technology (MRT) to bind a resin to the molecular properties of rare earths to separate them from the molecular properties of the deposit they are found in. In tests conducted at the SuperLig-One pilot plant in Utah, the rare earth element dysprosium was successfully separated from the MRT solution known as Bokan PLS (pregnant leach solution) with $99 \%$ recovery of dysprosium (Ucore).

Based on the success of the pilot facility, Ucore Rare Metals Inc. is proposing the construction of a Strategic Materials Complex near Ketchikan, Alaska (Lesley 2018). This complex would allow Ucore to scale up its use of the process in its development activities in its Bokan and Ray Mountain projects, both located near Ketchikan, Alaska (Ucore, Lesley 2018). Such a project could provide the United States military with a secure domestic supply of rare earths. On this front, the DOD could partner with the Department of Energy to further develop this technology. The Department of Energy has been supporting research into the use of coal ash (Gabriel 2019).

Ucore President and CEO Jim McKenzie has touted the company as being uniquely equipped to be a key source of rare earths and related mining technologies for the Department of Defense. The company has also indicated that it may be willing to strike a deal with the DOD to license its MRT technology to the U.S. military (Lesley 2018).

\section{FORMULATING A STRATEGY}

These discrete options can be used as building blocks for crafting a comprehensive U.S. strategy, the goal of which should be to increase the resiliency of the defense industrial base to a future supply shock from China (i.e., the threat scenario). One approach (but not necessarily the only approach) to strategy development is a sequence of four steps: a national security prioritization by element and application, qualitative identification of opportunity cost, classification of uncertainty combined with value of information (VOI) analysis, and strategy formulation with a focus on the most pressing needs. 
Before beginning such an exercise, the threat scenario should be defined. For example, a plausible scenario might be a repeat of the 2010 Senkaku Islands incident, in terms of both the actions China might take (a lowering of export quotas, a prohibition of exports to Japan for a period of time) and the global market reaction (price spikes, shortages of a particular magnitude and duration) that was observed. Defining and garnering agreement on this threat scenario is critically important for development of a national strategy.

Once the threat scenario is defined, the first step of strategy development is prioritization of national security risk. This is necessary because the number of rare earth elements, their supply chains, their applications, and their national security risk profile differ. In this step, each unique elementapplication combination is prioritized as posing a high, medium, or low national security risk. To do this, all major uses of each rare earth element must be identified and briefly described. For each unique element-use combination, a group of experts assigns a threat level. Each threat level should have an objective definition sufficient to engender a common understanding among the experts. As a result of the exercise, priorities are determined. For example, experts might determine that neodymium $(\mathrm{Nd})$ permanent magnets represent a high priority risk.

The second step is identification of the opportunity cost associated with each high priority threat based on the threat scenario. Opportunity cost is the true economic cost of increasing resiliency, which is the next best option compared against the status quo as a response to the threat scenario. In this exercise, a group of experts defines the opportunity cost. Consensus among the experts is desirable; unanimity is not required. For example, the opportunity cost of the status quo for $\mathrm{Nd}$ permanent magnets may be to stockpile sufficient quantities of $\mathrm{Nd}$ to weather against the threat scenario.

The third step is uncertainty analysis enabled by value of information (VOI) analysis. It may be that the opportunity cost of certain element- application combinations is highly uncertain relative to the others. In cases where uncertainty is high and the opportunity cots is highly variable, it is often useful to commit a small amount of resources for information gathering, when the information can increase certainty. A value of information (VOI) approach is ideally suited as a decisional tool for just these cases (Yokota \& Thompson 2004). The goal of this exercise is to identify specific information needs that can be addressed cost effectively. The information gathering can then be listed as an action item within the final strategy. For example, it may be that determining the needed stockpile amount for $\mathrm{Nd}$ depends crucially on future demand in a particular commercial application (smart phones), and better information on future demand would allow for greater certainty over the size of the needed stockpile. A plan to obtain such information (and the cost effectiveness of obtaining this information) would thus be identified.

The final step is strategy formulation based on the output of the first three steps. Here, it will be important to look at the opportunity cost for each high priority threat and determine how best to group these various options into a cohesive strategy. It may be that certain commonalities across the elementapplication combinations will allow major components of the strategy to be readily identified. For example, it may be that stockpiling of three key elements for particular uses (and the magnitude of the stockpile for each element) becomes a key element of the overall strategy.

The resulting strategy can and should be revisited periodically against the goal of increasing resiliency. One key parameter to revisit is the threat scenario. New circumstances may require the threat scenario to change. It should also be noted that the albeit simplistic approach described here could be altered to provide greater specificity or a range of strategic options dependent upon resource levels and/or multiple threat scenarios. 
Importantly, the U.S. government is taking steps consistent with this strategy development process:

--In July of 2019, President Trump exercised his Title III authorities pursuant to the Defense Production Act of 1950 to mobilize the DOD's resources to support and expand the development of domestic rare earth production capabilities (Trump, Presidential Determination Pursuant to Section 303 of the Defense Production Act of 1950, as amended 2019).

--DOD has followed up on the GAO's 2016 report recommendations to develop a standard definition of criticality across all DOD agencies. This would govern which rare earths are critical to national security. The DOD has also agreed with the GAO's recommendation to re-evaluate its mitigation strategies for ensuring the secure and reliable supply of rare earths. The results of the DOD's meetings to specifically address these recommendations are for official use only, and not available to the public (Government Accountability Office 2016).

--In December of 2017, President Trump issued an executive order directing the Secretary of the Interior to lead the relevant executive agenciesincluding the Department of Defense - in publishing a list of minerals critical to the U.S. Defense Industrial Base. The Department of the Interior released a finalized list of 35 minerals in May 2018. This list included the entire set of rare earth elements (Office of the Secretary of the Interior 2018).

--The executive order also issued a directive for the Department of Commerce to lead an interagency effort to develop and issue a report aimed at implementing a multi-pronged federal policy for reducing U.S. vulnerability to critical mineral supply chain disruptions (Trump 2018). The Department of Commerce had an August 16, 2018 deadline to provide the President with its report. It is difficult to know what a final list might look like, as the Department of Commerce has not released this report to the public.

\section{CONCLUSIONS}

The 2018 National Defense Strategy makes clear that the world has entered a new era of longterm strategic competition with revisionist powers, such as Russia and China, and rogue nations such as North Korea and Iran. Such a security environment requires that the United States maintain its military edge in order to protect its national security interests. Currently, the United States defense industrial basea key component of its military strength - is confronted by a myriad of challenges, including an over-reliance on foreign powers for critical components across the military supply chain. China's near monopoly of the rare earths market impacts U.S. national security, making it a critical case of foreign dependency.

The DOD recognizes the challenge of continued reliance on a strategic competitor for rare earths - a critical component in more than 200 military and dual-use applications - and is taking steps to address this challenge. Policy options include maintaining the status quo, developing domestic supply capabilities, partnering with strategic allies, and innovation via substitution and/or recycling. The U.S. government can use these policy options to formulate a strategy to increase the resiliency of the defense industrial base to future supply shocks, based on the goal of minimizing opportunity cost.

\section{LITERATURE CITED}

Air Force Research Library, ManTech. 2013. Defense

Production Act, Title III Project Establishes Domestic Source for Beryllium.

https://www.wpafb.af.mil/News/Article-

Display/Article/819343/defense-production-act-title-iii-

project-establishes-domestic-source-for-beryll/.

American Geosciences Institute. 2018. What Are Rare Earths, and Why Are They Important?. https://www.americangeosciences.org/critical- 
issues/faq/what-are-rare-earths-and-why-are-theyimportant.

Annual Industrial Capabilities, Fiscal Year 2017. 34. 2018. Department of Defense.

Assessing and Strengthening the Manufacturing and Defense Industrial Base and Supply Chain Resiliency of the United States. 2018. Media Defense. https://media.defense.gov/2018/Oct/05/2002048904/-1/1/1/ASSESSING-AND-STRENGTHENING-THEMANUFACTURING-AND-DEFENSE-INDUSTRIALBASE-AND-SUPPLY-CHAIN-RESILIENCY.PDF.

Bourzac, K. 2011. The Rare-Earth Crisis. https://www.technologyreview.com/s/423730/the-rareearth-crisis/.

Bradsher, K. 2010. Amid Tension, China Blocks Vital Exports to Japan. The New York Times. https://www.nytimes.com/2010/09/23/business/global/23r are.html.

China Restarts Rare Earth Shipments to Japan. 2010. The New York Times.

https://www.nytimes.com/2010/11/20/business/global/20r are.html.

Canan, J.W. 2006. The Changing Defense Industrial Base. Aerospace America 44 (8): 34-38.

Chovanec, P. 2010. The Politics of Rare Earth. Forbes. https://www.forbes.com/sites/china/2010/10/04/thepolitics-of-rare-earth/\#6df3c38ad835.

Defense Logistics Agency. Annual Materials Plan Archive. https://www.dla.mil/HQ/Acquisition/StrategicMaterials/R eports/Annual-Materials-Plan-Archive/ .

The Defense Production Act of 1950: History, Authorities, and Considerations for Congress. 2018.

https://fas.org/sgp/crs/natsec/R43767.pdf.

DPA Title III Overview. https://www.businessdefense.gov/DPA-TitleIII/Overview/.
Federal Register: Final List of Critical Minerals 2018. 2018. Office of the Secretary of the Interior. https://www.federalregister.gov/documents/2018/05/18/20 18-10667/final-list-of-critical-minerals-2018.

Gabriel, B., McKenzie, C. 2019. DLA Approach to Rare Earths Dependency Challenge (February 15). Interview by Raeanna McFadden Keith Belton.

Gayonnet, D. 2018. Rare Earth Elements and High-Tech Products. White Paper, Circular Economy Coalition for Europe.

The Geopolitics of Rare Earth Elements. 2019. Stratfor Worldview. https://worldview.stratfor.com/article/geopolitics-rareearth-elements.

Grasso, V.B. 2013. Rare Earth Elements in National Defense: Background, Oversight Issues, and Options for Congress. Congressional Research Service. https://fas.org/sgp/crs/natsec/R41744.pdf.

Jensen, T.C., Snodgrass, S.A., Castelli, M. 2016. Infrastructure Permit Streamlining Under the FAST Act. Holland \& Hart.

John S. McCain National Defense Authorization for Fiscal Year 2019. 2018. Government Publishing Office. https://www.govinfo.gov/content/pkg/BILLS115hr5515enr/pdf/BILLS-115hr5515enr.pdf.

Kennedy, J. 2019. China Solidifies Dominance in Rare Earths Processing. National Defense Magazine. http://www.nationaldefensemagazine.org/articles/2019/3/2 1/viewpoint-china-solidifies-dominance-in-rare-earthprocessing.

Lesley, S. 2018. Pentagon Funding Bans China Rare Earths. North of 60 Mining News. https://www.miningnewsnorth.com/story/2018/08/17/new s-nuggets/pentagon-funding-bans-china-rareearths/5312.html.

Lovins, A. 2017. Clean Energy and Rare Earths: Why Not to Worry. The Bulletin. 
https://thebulletin.org/2017/05/clean-energy-and-rareearths-why-not-to-worry/.

Math, P.F. 1993. Defense Industrial Base: An Overview of an Emerging Issue, GAO/NSIAD 93-68. Government Accountability Office. https://www.gao.gov/assets/220/217775.pdf.

Mineral Commodity Summaries: Domestic Production and Use. 2018. United States Geological Survey. https://minerals.usgs.gov/minerals/pubs/commodity/rare_e arths/mcs-2018-raree.pdf .

Mission Summary: SuperLig-One Pilot Plant. Ucore. https://ucore.com/superlig-one.

Plumer, B. 2012. China's Grip on the World's Rare Earth Market May Be Slipping. The Washington Post. https://www.washingtonpost.com/news/wonk/wp/2012/10 /19/chinas-chokehold-over-rare-earth-metals-isslipping/?utm_term=.e393e00d5dfb.

Rare Earth Materials: Developing a Comprehensive Approach Could Help DoD Better Manage National Security Risks in the Supply Chain. 2016. Government Accountability Office.

https://www.gao.gov/assets/680/675165.pdf.

Rare Earth Elements: What Are Rare Earths? 2016. Rare Element Resources.

http://www.rareelementresources.com/rare-earthelements\#.XNWKLy_MxQI.

Rare Earths. Ucore. https://ucore.com.

Romans, Colonel S.F. 2008. The Role of the National Defense Stockpile in the Supply of Strategic and Critical Materials. https://apps.dtic.mil/dtic/tr/fulltext/u2/a486768.pdf.

Roos, D. 2017. China's Monopoly on Rare Earth Elements Tightens With Purchase of U.S. Mine. https://www.seeker.com/tech/materials/chinas-monopolyon-rare-earth-elements-tightens-with-purchase-of-usmine.
Rupp, J. 2019. Interview by Personal Communication Former USGS Official (retired).

Thomas-Boone, B. 2017. U.S. Third Offset (part 2): Opportunities for Australia. The Strategist. https://www.aspistrategist.org.au/us-third-offset-part-2opportunities-for-australia/.

Title 10-Armed Forces Section 2508 Industrial Base Fund. 2010. Government Publishing Office. https://www.govinfo.gov/content/pkg/USCODE-2010title10/pdf/USCODE-2010-title10-subtitleA-partIVchap148-subchapII-sec2508.pdf.

Trump, President D.J. 2018. Presidential Executive Order on a Federal Strategy to Ensure Secure and Reliable Supplies of Critical Minerals. The United States of America. https://www.whitehouse.gov/presidentialactions/presidential-executive-order-federal-strategyensure-secure-reliable-supplies-critical-minerals/ .

U.S. Military Dangerously Dependent on Foreign Suppliers, Claims Study. 2013. Metal/Center News 53(7): 4-5.

Vekasi, Kristin. 2019. "Politics, Markets, and Rare Earth Commodities: Responses to China's Rare Earth Policy." Japanese Journal of Political Science 20: 2-20.

In Victory for the West, W.T.O. Orders China to Stop Export Taxes on Minerals. 2012. The New York Times. https://www.nytimes.com/2012/01/31/business/wtoorders-china-to-stop-export-taxes-on-minerals.html.

What Are Rare Earths? 2018. Rare Earth Technology Alliance. http://www.rareearthtechalliance.com/What-areRare-Earths.

Wilson, J.D. 2018. Whatever Happened to the Rare Earths Weapon? Critical Materials and International Security in Asia. Journal of Asian Security 14(3): 358-373.

Yokota F., Thompson, K.M. 2004. Value of Information Literature Analysis: A Review of Applications in Health Risk Management. Medical Decision Making 24(3): 287298. 
Yin, R.K. 1994. Chapter One: Designing a Case Study. Case Study Research: Design and Methods. Second Edition, Thousand Oaks, California: Sage Publications. 2017 Special 301 Report. 2018. United States Trade Representative.
https://ustr.gov/sites/default/files/Section\%20301\%20FIN AL.PDF.

\section{APPENDIX A}

John S McCain National Defense Authorization Act 2019:

$$
\text { H. R. } 5515-270
$$

“(A) a commercially available off-the-shelf item (as defined in section 104 of title 41), other than-

"(i) a commercially available off-the-shelf item that is 50 percent or more tungsten by weight; or

"(ii) a mill product, such as bar, billet, slab, wire, cube, sphere, block, blank, plate, or sheet, that has not been incorporated into an end item, subsystem, assembly, or component;

"(B) an electronic device, unless the Secretary of Defense, upon the recommendation of the Strategic Materials Protection Board pursuant to section 187 of this title, determines that the domestic availability of a particular electronic device is critical to national security; or

"(C) a neodymium-iron-boron magnet manufactured from recycled material if the milling of the recycled material and sintering of the final magnet takes place in the United States.

“(d) DEFINITIONS.-In this section:

"(1) COVERED MATERIAL.-The term 'covered material' means-

“(A) samarium-cobalt magnets;

"(B) neodymium-iron-boron magnets;

“(C) tungsten metal powder; and

"(D) tungsten heavy alloy or any finished or semifinished component containing tungsten heavy alloy.

"(2) COVERED NATION.- The term 'covered nation' means-

“(A) the Democratic People's Republic of North Korea;

"(B) the People's Republic of China;

"(C) the Russian Federation; and

"(D) the Islamic Republic of Iran.

“(3) END ITEM.-The term 'end item' has the meaning given in section $2533 \mathrm{~b}(\mathrm{~m})$ of this title.".

(b) CLERICAL AMENDMENT.-The table of contents at the beginning of such subchapter is amended by inserting after the item relating to section $2533 \mathrm{~b}$ the following item:

"2533c. Prohibition on acquisition of sensitive materials from non-allied foreign nations.".

\section{Subtitle H-Other Matters}

SEC. 871. PROHIBITION ON ACQUISITION OF SENSITIVE MATERIALS FROM NON-ALLIED FOREIGN NATIONS.

(a) IN GENERAL. Subchapter V of chapter 148 of title 10, United States Code, is amended by inserting after section 2533b the following new section:

“\$2533c. Prohibition on acquisition of sensitive materials from non-allied foreign nations

“(a) IN GENERAL.-Except as provided in subsection (c), the Secretary of Defense may not-

"(1) procure any covered material melted or produced in any covered nation, or any end item that contains a covered material manufactured in any covered nation, except as provided by subsection (c); or

"(2) sell any covered material from the National Defense Stockpile, if the National Defense Stockpile Manager determines that such a sale is not in the national interests of
the United States, to"(A) any covered nation; or

“(B) any third party that the Secretary reasonably believes is acting as a broker or agent for a covered nation (b) APPLICABILITY. - Subsection (a) shall apply to prime contracts and subcontracts at any tier.

"(c) EXCEPTIONS.-Subsection (a) does not apply under the following circumstances:

"(1) If the Secretary of Defense determines that covered materials of satisfactory quality and quantity, in the required form, cannot be procured as and when needed at a reasonable price.

"(2) To the procurement of an end item described in subsection (a)(1) or the sale of any covered material described under subsection (a)(1) by the Secretary outside of the United

States for use outside of the United States. containing a covered material that is- 